\title{
KEEFEKTIFAN MEDIA PEMBELAJARAN FLASHCARD DALAM KETERAMPILAN MENULIS KARANGAN SEDERHANA BAHASA JERMAN SISWA KELAS XI IPA SMA NEGERI 9 MAKASSAR
}

\author{
Femmy Angreany ${ }^{1}$ dan Syukur Saud ${ }^{2}$ \\ Fakultas Bahasa dan Sastra, Universitas Negeri Makassar \\ Email ${ }^{1}$ : femmyangreany@gmail.com
}

\begin{abstract}
ABSTRAK
Penelitian ini dilakukan untuk memeroleh data dan informasi tentang keefektifan media Flashcard dalam keterampilan menulis karangan sederhana bahasa Jerman. Penelitian ini adalah penelitian Quasi-eksperimen. Pengumpulan data melalui tes keterampilan menulis karangan sederhana. Populasi penelitian ini adalah siswa kelas XI IPA SMA Negeri 9 Makassar yang terdiri dari 2 kelas yang hanya belajar bahasa Jerman yang berjumlah 70 siswa. Sampel dalam penelitian ini adalah total sampling. Jumlah sampel 70 siswa, dan semua siswa tersebut dijadikan partisipan dimana dibagi menjadi 2 kelas yakni kelas kontrol dan eksperimen. Data dianalisis menggunakan analisis Uji-t. Hasil analisis data menunjukkan bahwa $t_{h} 6,17>t_{t} 1,998$ pada taraf signifikan 0,05 . Hasil penelitian menunjukkan bahwa media pembelajaran Flashcard efektif digunakan dalam keterampilan menulis karangan sederhana bahasa Jerman siswa kelas XI IPA SMA Negeri 9 Makassar.
\end{abstract}

\section{Kata Kunci : Efektivitas, Flashcard, Keterampilan Menulis}

\begin{abstract}
The purpose of this study was to know the effectiveness of Flashcard media in writing a german language simple essay. This study used quasy-experiment approach. Data was collected using writing skill test. Population of this study was students of XI IPA SMA Negeri 9 Makassar which consisted of 2 classes which had 70 students. All the students were chosen as participant divided into 2 clasess, experiment class and control class. Data were analyzed using t-Test analysis. The result of data analysis shows that $t_{h} 6.17>t_{t} 1.998$ at significant level of 0.05 . The results showed that Flashcard learning media effectively used in the skill of writing simple essay of German class XI students IPA SMA Negeri 9 Makassar.
\end{abstract}

Keywords: Effectiveness, Flashcards, Writing Skills

\section{PENDAHULUAN}

Salah satu aspek penting dalam diri manusia adalah kemampuan untuk berkomunikasi. Komunikasi adalah suatu proses penyampaian informasi dari satu pihak kepada pihak lain. Agar penyampaian informasi tersebut dapat dipahami maka dalam berkomunikasi diperlukan sarana atau alat yang telah disepakati bersama yaitu bahasa. Bahasa sebagai alat komunikasi dalam kehidupan sehari-hari merupakan hal yang tidak dapat terpisahkan dari kehidupan manusia sebagai makhluk sosial. Bahasa senantiasa mendampingi kegiatan manusia dalam berkomunikasi. 
Dengan bahasa manusia dapat mengekspresikan diri, menyampaikan pikiran, keinginan dan maksud kepada orang lain baik secara lisan maupun tulisan.

Era globalisasi saat ini juga tidak terlepas dari peranan bahasa. Banyaknya pertukaran informasi antarnegara melalui berbagai media canggih yang menyajikan berbagai macam informasi mulai bermunculan dengan berbagai macam bahasa pula. Hal tersebut menjadi salah satu ciri globalisasi dan bahasa menjadi salah satu bagian yang sangat penting dalam pertukaran informasi saat ini. Oleh sebab itu, manusia dituntut untuk mampu menguasai dan menggunakan berbagai bahasa, tidak hanya sebatas menguasai bahasa Indonesia sebagai bahasa nasional tapi juga bahasa Asing sebagai bahasa Internasional.

Salah satu bahasa asing yang terkait di atas, yaitu bahasa Jerman. Bahasa Jerman merupakan bahasa yang banyak digunakan di negara-negara Eropa. Begitupun di Indonesia, bahasa Jerman merupakan bahasa yang telah diajarkan di sekolahsekolah secara formal pada jenjang pendidikan menengah seperti SMA/SMK dan MA. Hal tersebut merupakan wujud kesadaran dari pentingnya penguasaan bahasa asing, khususnya bahasa Jerman guna membentuk individu yang berkualitas yang siap menghadapi era globalisasi (Mantasiah, 2016). Keterampilan menulis merupakan salah satu dari keempat aspek dalam bahasa Jerman yang memiliki peran penting, dengan menulis, seseoarang dapat mengungkapkan ide, pikiran, perasaan kepada orang lain secara tertulis begitupun dalam pembelajaran bahasa Jerman, sesuai dengan Permendiknas Nomor 22 Tahun 2006 tentang Standar Isi dan Permendiknas
Nomor 23 Tahun 2006 tentang Standar Kompetensi Lulusan, Komptensi Dasar berdasarkan kurikulum KTSP dalam keterampilan menulis bahasa Jerman tingkat sekolah menengah atas dan Madrasah Aliyah siswa seharusnya mampu untuk menulis kata, frasa, dan kalimat dengan huruf, ejaan, dan tanda baca yang tepat serta mampu untuk mengungkapkan segala bentuk ide, pikiran, dan gagasannya yang dituangkan dalam bentuk sebuah wacana atau karangan terkait tema yang sedang dipelajari, namun pada kenyataannya, keterampilan menulis merupakan keterampilan yang kurang dikuasai oleh siswa dalam pembelajaran bahasa Jerman di sekolah.

Hal tersebut berdasarkan hasil observasi dan wawancara pengajar bahasa Jerman di SMA Negeri 9 Makassar pada tanggal 7 September 2016 diperoleh informasi bahwa siswa masih mengalami kesulitan dalam keterampilan menulis bahasa Jerman hal tersebut diperkuat dari tugas dan data nilai rapor keterampilan menulis siswa SMA Negeri 9 Makassar yang mendapatkan nilai di bawah standar Kriteria Ketuntasan Minimal (KKM) yaitu nilai 70. Selain itu, terdapat berbagai permasalahan mengenai keterampilan menulis yang dialami oleh siswa, permasalahan tersebut diantaranya, kurangnya motivasi siswa untuk berlatih menulis, ketidaktahuan siswa mengenai apa yang akan dituliskan karena kesulitan ingin memulai tulisan itu dari mana, takut melakukan kesalahan serta teknik pembelajaran konvensional belum menggunakan teknik pembelajaran yang inovatif dinilai kurang kreatif sehingga tidak sedikit siswa merasa bosan. 
Berbagai macam permasalahan tersebut dapat diatasi dengan menerapkan media pembelajaran. Saat ini terdapat berbagai macam media yang dapat digunakan dalam pembelajaran, diantaranya media grafis, audio, tiga dimensi dan multimedia. Dari beberapa media tersebut, media grafis berupa Flashcard atau kartu-kartu bergambar merupakan media yang dapat digunakan dalam pembelajaran keterampilan menulis bahasa Jerman. Media pembelajaran Flashcard merupakan media yang mengharuskan siswa untuk menulis sebuah karangan sederhana berdasarkan Flashcard atau kartu-kartu bergambar yang didapatkan oleh siswa.

\section{MEDIA FLASHCARD}

Flashcard merupakan salah satu media pembelajaran yang berbentuk grafis berupa kartu kecil bergambar, biasanya terbuat dengan menggunakan foto, simbol, atau gambar yang ditempelkan pada sisi depan dan pada sisi belakang terdapat keterangan berupa kata atau kalimat dari gambar Flashcard tersebut. Media pembelajaran Flashcard mengingatkan atau mengarahkan siswa kepada sesuatu yang berhubungan dengan gambar.

Buttner (2013:1) berpendapat yang ringkasannya yaitu Flashcard adalah media pembelajaran berupa gambar yang dilengkapi dengan kosakata atau pertanyaan-pertanyaan yang berkaitan dengan gambar. Sumber-sumber untuk membuat sebuah Flashcard yaitu klip rupa (clip art), gambar yang dibuat oleh siswa, gambar dari kalender, atau gambar dari majalah atau brosur. Lebih lanjut yang dikemukakan oleh Susilana dan Riyana (2009:94) "Flashcard adalah media pembelajaran dalam bentuk kartu bergambar yang berukuran $30 \times 50 \mathrm{~cm}$. Gambar-gambarnya dibuat dengan menggunakan tangan atau foto, atau memanfaatkan gambar/foto yang sudah ada yang ditempelkan pada lembaran-lembaran Flashcard'. Hal senada juga dikemukakan oleh Indriana (2011:68) "Flashcard adalah media pembelajaran dalam bentuk kartu bergambar yang ukurannya seukuran Postcard atau sekitar 25 x $30 \mathrm{~cm}$. Gambar yang ditampilkan dalam kartu tersebut adalah gambaran tangan atau foto, atau gambar/foto yang sudah ada dan ditempelkan pada lembaran kartu-kartu tersebut". Adapun menurut Arsyad (2016:115) "Flashcard adalah kartu kecil yang berisi gambar, teks, atau tanda simbol yang mengingatkan atau menuntun siswa kepada sesuatu yang berhubungan dengan gambar. Flashcrd berukuraan 8 x $12 \mathrm{~cm}$, atau dapat disesuaikan dengan besar kecilnya kelas yang dihadapi”.

Lebih lanjut lagi Arsyad (2016:115) menjelaskan bahwa: "Penggunaan media Flashcard dalam pembelajaran merupakan suatu proses, cara menggunakan kartu belajar yang efektif berisi gambar, teks, atau tanda simbol untuk membantu mengingatkan atau mengarahkan siswa kepada sesuatu yang berhubungan dengan gambar, teks, atau tanda simbol yang ada pada kartu, serta merangsang pikiran dan minat siswa dalam meningkatkan kecakapan pengenalan simbol bahan tulis dan kegiatan menurunkan simbol tersebut sampai kepada kegiatan siswa memahami arti/makna yang terkandung dalam bahan tulis".

Flashcard merupakan sebuah media pembelajaran yang dalam penerapannya memerlukan langkah-langkah agar penyajiannya dapat berjalan sebagaimana 
mestinya. Beberapa langkah-langkah penggunaan media pembelajaran Flashcard yang dikemukakan oleh Buttner (2013:2) yaitu "Berikan kepada murid-murid yang bekerja secara berkelompok sekumpulan Flashcard berisi bermacam-macam kata atau gambar. Mintalah mereka untuk menggunakan semua Flashcard secara kreatif untuk menyusun kalimat, pertanyaan, membuat kalimat pernyataan benar atau salah, atau menulis cerita dengan menggunakan kosakata yang tercantum pada kartu-kartu tersebut".

Lebih lanjut langkah-langkah penggunaan media pembelajaran Flashcard yang diuraikain oleh Indriana (2011:68-69) yaitu: “(1) Kartu-kartu yang telah disusun dipegang setinggi dada dan menghadap ke siswa; (2) Cabut kartu satu per satu setelah guru selesai menerangkan; (3) Berikan kartu-kartu yang telah diterangkan tersebut kepada siswa yang dekat dengan guru. Mintalah siswa untuk mengamati kartu tersebut, selanjutnya diteruskan kepada siswa lain hingga semua siswa mengamati. (4) Jika sajian menggunakan cara permainan: (a) Letakkan kartu-kartu secara acak pada sebuah kotak yang berada jauh dari siswa; (b) Siapkan siswa yang akan berlomba; (c) Guru memerintahkan siswa untuk mencari kartu yang berisi gambar, teks, atau lambang sesuai."

Setiap media pembelajaran memiliki sebuah kelebihan dan kekurangan masingmasing, begitupun dengan media pembelajaran Flashcard. Adapun kelebihan dan kekurangan media pembelajaran Flashcard yang dikemukanan oleh Susilana dan Riyana (2009:95) yaitu : (1) mudah dibawa-bawa, dengan ukuran yang kecil Flashcard dapat disimpan ditas bahkan disaku, dapat digunakan dimana saja, di kelas ataupun di luar kelas; (2) praktis, dalam menggunakan media ini guru tidak perlu memiliki keahlian khusus, media ini tidak perlu juga membutuhkan listrik. Jika akan menggunakan kita tinggal menyusun urutan gambar sesuai dengan keinginan kita, jika sudah digunakan tinggal disimpan kembali dengan cara diikat atau menggunakan kotak khusus supaya tidak tercecer; (3) gampang diingat, karakteristik media Flashcard adalah menyajikan pesanpesan pendek pada setiap kartu yang disajikan. Sajian pesan-pesan pendek ini akan memudahkan siswa untuk mengingat pesan tersebut; (4) menyenangkan, media Flashcard dalam peggunaannya bisa melalui permainan. Misalnya siswa secara berlomba untuk mencari sesuai perintah. Selain mengasah kemampuan kognitif juga melatih ketangkasan (fisik).

Pendapat lain dikemukakan oleh Sadiman (2006:29) bahwa kelebihan media pembelajaran Flashcard adalah "(1) sifatnya konkret, (2) gambarnya mengatasi keterbatasan ruang dan waktu, (3) dapat mengatasi keterbatasan kita,(4) dapat memperjelas masalah, (5) murah harganya dan mudah didapat serta mudah digunakan tanpa memerlukan peralatan khusus". Sementara itu Butnerr (2013:1) berpendapat bahwa "Media pembelajaran Flashcard dapat mendorong murid-murid yang penggugup untuk berani bangkit dari tempat duduknya dan mencobanya". Selain kelebihan, media Flashcard juga memiliki kelemahan seperti yang dikemukakan oleh Sadiman (2006:31) antara lain: “(1) gambar hanya menekankan persepsi indra mata, (2) gambar benda yang terlalu kompleks kurang efektif untuk kegiatan pembelajaran, dan (3) ukurannya sangat terbatas untuk kelompok besar". 


\section{METODE PENELITIAN}

Penelitian ini merupakan penelitian eksperimen yang bertujuan untuk mengetahui pengaruh yang ditimbulkan dari sebuah perlakuan (treatment). Penelitian ini menggunakan dua variabel yaitu variabel bebas $(\mathrm{X})$ dan variabel terikat (Y). Variabel bebas yang dimaksud adalah media pembelajaran Flashcard dan variabel terikat adalah keterampilan menulis karangan sederhana bahasa Jerman Siswa Kelas XI IPA SMA Negeri 9 Makassar.

Desain penelitian yang digunakan adalah quasi experimental design (eksperimental-semu) nonequivalent control group design. Variabel yang digunakan dalam penelitian ini adalah penggunaan media pembelajaran Flashcard sebagai variabel bebas (X) dan keterampilan menulis karangan sederhana dengan tema die Familie bahasa Jerman Siswa Kelas XI IPA SMA Negeri 9 Makassar sebagai variabel terikat (Y).

Flashcard sebagai variabel bebas dalam penelitian ini adalah suatu media pembelajaran yang berbentuk gambar yang terdiri dari kartu-kartu bergambar yang disertai dengan kosakata. Sedangkan keterampilan menulis karangan sederhana bahasa Jerman sebagai variabel terikat dalam penelitian ini adalah kemampuan siswa dalam menulis karangan sederhana bahasa Jerman dengan menggunakan Flashcard atau kartu-kartu bergambar yang disertai kosakata dengan tema die Familie.

Populasi dalam penelitian ini adalah seluruh siswa kelas XI IPA SMA Negeri 9 Makassar yang terdiri dari 2 kelas yang hanya mempelajari bahasa Jerman dengan jumlah siswa 70 siswa. Sampel yang digunakan dalam penelitian ini adalah sampel total (total sampling). Dari dua kelas XI IPA yang hanya mempelajari bahasa Jerman maka terpilihlah kelas XI IPA 6 sebanyak 35 siswa sebagai kelas eksperimen dan kelas XI IPA 7 sebanyak 35 siswa sebagai kelas kontrol melalui teknik undian. Jadi, total sampelnya adalah 70 siswa.

Prosedur pengumpulan data pada penelitian ini adalah sebagai berikut:

1. Tes awal (pre-test), yaitu tes keterampilan menulis karangan sederhana bahasa Jerman sesuai kata kunci yang diberikan kepada siswa dengan tema die Familie diawal penelitian baik kelas eksperimen maupun kelas kontrol yang bertujuan untuk mengetahui tingkat kemampuan awal siswa menulis karangan sederhana bahasa Jerman.

2. Tes akhir (post-test), yaitu tes keterampilan menulis karangan sederhana bahasa Jerman sesuai kata kunci yang diberikan kepada siswa dengan tema die Familie untuk mengetahui dan melihat perbandingan menulis karangan sederhana bahasa Jerman siswa setelah diajar dengan menggunakan media pembelajaran Flashcard dengan siswa yang tidak diajar dengan menggunakan media pembelajaran Flashcard.

Data yang diperoleh akan dianalisis menggunakan analisis statistik inferensial untuk menguji hipotesis penelitian dengan menggunakan uji-t. Namun sebelumnya, terlebih dahulu dilakukan uji normalitas dengan menggunakan tabel Z-score dan chi-kuadrat dan uji homogenitas dengan menggunakan uji $\mathrm{F}$ (Fisher), tetapi sebelum menentukan uji normalitas, uji homogenitas data, maupun uji hipotesis terlebih dahulu 
tentukan nilai rata-rata (mean), simpangun baku, dan varian.

\section{PEMBAHASAN}

Pada bagian ini akan dipaparkan hasil yang diperoleh dari analisis data penelitian tentang keefektifan media pembelajaran Flashcard dalam keterampilan menulis karangan sederhana bahasa Jerman siswa kelas XI IPA SMA Negeri 9 Makassar. Media pembelajaran ini merupakan suatu alternatif dalam pembelajaran bahasa Jerman khususnya keterampilan menulis karangan bahasa Jerman, karena membuat siswa menjadi aktif dan kreatif dalam membuat sebuah karangan berdasarkan Flashcard atau kartu bergambar yang didapatkan oleh siswa.

Pada penelitian ini, diperoleh sampel melalui total sampel (total sampling) yakni kelas XI IPA 6 sebagai kelas eksperimen dan XI IPA 7 sebagai kelas kontrol. Pembelajaran dilakukan selama 3 kali pertemuan setelah pemberian pre-test pada masing-masing kelas. Namun pembelajaran pada dua kelas tersebut dilakukan secara berbeda, siswa pada kelas eksperimen diajar dengan menggunakan media pembelajaran Flashcard sedangkan siswa pada kelas kontrol diajar tanpa menggunakan media pembelajaran Flashcard.

Dalam penelitian ini, pre-test yang diberikan untuk mengetahui kemampuan awal siswa dalam keterampilan menulis karangan sederhana menunjukkan bahwa kelas eksperimen (XI IPA 6) memeroleh nilai rata-rata (mean) sebesar 49,39 dengan hasil analisis menunjukkan bahwa 7 siswa (20,0\%) memeroleh nilai terendah, yaitu 29 dan 23 siswa $(65,71 \%)$ memeroleh nilai tertinggi yaitu 57, sementara kelas kontrol (XI IPA 7) memeroleh nilai rata-rata (mean) sebesar 46,60 dengan hasil analisis menunjukkan bahwa 8 siswa $(22,86 \%)$ memeroleh nilai terendah, yaitu 29 dan 17 siswa $(48,57 \%)$ memeroleh nilai tertinggi yaitu 57. Rendahnya perolehan nilai pada kedua kelas tersebut dikarenakan informasi yang disampaikan dalam tulisan tidak terlalu komunikatif, beberapa bagian penulisan terdapat banyak kesalahan, serta kalimat yang ditulis juga terdapat banyak kesalahan baik secara leksik, morfologi, sintaksis dan ortografis sehingga tidak dapat dimengerti.

Hasil nilai pre-tes tersebut kemudian di uji dengan menggunakan uji normalitas dan uji homogenitas. Uji normalitas dimaksudkan untuk mengetahui apakah kedua sampel yang diteliti berdistribusi normal atau tidak, sedangkan uji homogenistas dimaksudkan untuk mengetahui apakah kedua sampel dalam penelitian tersebut homogen atau tidak. Hasil analisis uji normalitas menunjukkan bahwa harga yang diperoleh pada kelas eksperimen (XI IPA 6) dan kelas kontrol (XI IPA 7) masing-masing sebesar 232,615 dan -211,186. Hasil tersebut kemudian dikonsultasikan dengan tabel chikuadrat $(\mathrm{dk}=50$, taraf signinfikasi 0,05$)$ sebesar 11,07 menunjukkan bahwa $\mathrm{x}^{2}{ }_{\text {hitung }}<$ $\mathrm{x}^{2}$ tabel $(-232,615<11,07)$ dan $(-211,186<$ 11,07), begitupun data post-test yang diperoleh pada kedua kelas tersebut masing-masing sebesar -162,695 dan 201,747. Hasil tersebut kemudian dikonsultasikan dengan tabel chi-kuadrat $(\mathrm{dk}=50$, taraf signinfikasi 0,05) sebesar 11,07 menunjukkan bahwa $\mathrm{x}^{2}$ hitung < $x^{2}$ tabel $(-162,695<11,07)$ dan $(-201,747<$ 11,07), sehingga distribusi data pre-test dan post-test dinyatakan normal, artinya tes yang diberikan sesuai dengan kemampuan 
siswa. Adapun hasil uji homogenitas menunjukkan bahwa nilai $F_{\text {hitung }}$ pada kelas ekperimen dan kontrol adalah 1,01. Hasil tersebut dikonsultasikan dengan $F_{\text {tabel }}$ $(\mathrm{dk}=5$, taraf signinfikasi 0,05) sebesar 5,05 menunjukkan bahwa $F_{\text {hitung }}$ lebih kecil daripada $F_{\text {tabel. }}(1,01<5,05)$. Hal ini berarti bahwa kelompok data pada kelas eksperimen dan kontrol dinyatakan homogen.

Selanjutnya diberikan perlakuan, yakni kelas eksperimen diajar dengan menggunakan media pembelajaran Flashcard sedangkan siswa pada kelas kontrol diajar tanpa menggunakan media pembelajaran Flashcard. Setelah 3 kali pertemuan kedua kelas tersebut kembali diberi tes (post-test) menulis karangan sederhana bahasa Jerman, dari hasil posttest pada kelas eksperimen (XI IPA 6) yang diajar dengan menggunakan media pembelajaran Flashcard mengalami peningkatan nilai yang cukup signifikan. Hal ini dapat dilihat dengan perolehan nilai untuk kelas eksperimen, hanya satu siswa $(2,86 \%)$ yang memeroleh nilai terendah yaitu, 29 dan 10 siswa $(28,57 \%)$ yang memeroleh nilai tertinggi, yaitu 86 dengan rata-rata 70,61 yang sebelumnya hanya 49,39. Siswa telah mampu menyampaikan informasi yang disampaikan dalam tulisan dengan sangat komunikatif sesuai dengan tema serta kalimat-kalimat yang ditulis hanya mengandung sedikit kesalahan leksik, morfologi, sintaksis, dan ortografis tetapi tidak mengganggu urutan sistematika penulisan dalam karangan bahasa Jerman tersebut.

Adapun kelas kontrol yang belajar tanpa menggunakan media pembelajaran tidak mengalami peningkatan nilai yang begitu signifikan pada kelas eksperimen, perolehan nilai menunjukkan bahwa 1 siswa $(2,86 \%)$ yang memeroleh nilai terendah, yaitu 14 dan hanya 4 siswa $(11,43 \%)$ yang memeroleh nilai tertinggi, yaitu 71 dengan nilai rata-rata 50,57. Tidak seperti pada kelas eksperimen, informasi yang disampaikan oleh siswa dalam tulisan tidak terlalu komunikatif bahkan terdapat tulisan yang tidak dimengerti dan tidak sesuai dengan tema, serta kalimat yang ditulis terdapat banyak kalimat yang ditulis terdapat banyak kesalahan baik secara leksik, morfologi, sintaksis dan ortografis sehingga tidak dapat dimengerti.

Selanjutnya dilakukan pengujian hipotesis dengan menggunakan uji-t untuk mengetahui hasil akhir dari penelitian ini, yaitu ada tidaknya perbedaan tingkat keterampilan menulis karangan sederhana bahasa Jerman pada hasil postes kelas eksperimen dan kelas kontrol. Hasil penghitungan tersebut diperoleh data bahwa $\mathrm{t}_{\text {hitung }}$ sebersar 6,17. Setelah dikonsultasikan dengan $t_{\text {tabel }}$ pada taraf signifikansi 5\% $(0,05)$ dan df 68 sebesar 1,998 maka dapat disimpulkan bahwa t-hitung ( $\mathrm{t}_{\text {hitung }}$ ) lebih besar daripada $\mathrm{t}$-tabel ( $\mathrm{t}_{\text {tabel }}$ ) yakni $\mathrm{t}_{\text {hitung }}$ $(6,17)>t_{\text {tabel }}(1,998)$. Dengan demikian $\mathrm{H}_{1}$ yang menyatakan bahwa ada perbedaan yang signifikan antara keterampilan menulis karangan sederhana bahasa Jerman siswa kelas XI IPA SMA Negeri 9 Makassar yang diajar dengan menggunakan media pembelajaran Flashcard dan siswa yang tidak diajar dengan menggunakan Flashcard dinyatakan diterima. Dan $\mathrm{H}_{\mathrm{o}}$ yang menyatakan bahwa tidak ada perbedaan yang signifikan antara keterampilan menulis karangan sederhana bahasa Jerman siswa kelas XI IPA SMA Negeri 9 Makassar yang diajar dengan menggunakan media pembelajaran 
Flashcard dan siswa yang tidak diajar dengan menggunakan media pembelajaran Flashcard dinyatakan ditolak.

Berdasarkan uraian tersebut dapat disimpulkan bahwa penelitian tentang keefektifan media pembelajaran Flashcard dalam keterampilan menulis karangan sederhana bahasa Jerman siswa kelas XI IPA SMA Negeri 9 Makassar dinyatakan berhasil atau efektif digunakan dalam pembelajaran keterampilan menulis karangan sederhana bahasa Jerman, hal tersebut sejalan dengan teori yang dikemukakan oleh Arsyad (2016:115) bahwa penggunaan media Flashcard dalam pembelajaran merupakan suatu proses, cara menggunakan kartu belajar yang efektif berisi gambar, teks, atau tanda simbol untuk membantu mengingatkan atau mengarahkan siswa kepada sesuatu yang berhubungan dengan gambar, teks, atau tanda simbol yang ada pada kartu, serta merangsang pikiran dan minat siswa dalam meningkatkan kecakapan dan kegiatan menurunkan simbol tersebut sampai kepada kegiatan siswa memahami arti/makna yang terkandung dalam bahan tulis. Hal senada juga dikemukakan oleh Wulansari (2014:32) yang menyatakan bahwa media Flashcard yang di dalamnya terdapat kosakata akan membantu mempermudah peserta didik dalam membuat karangan. Dengan demikian, tujuan pembelajaran yang menggunakan media Flashcard ini akan lebih mudah tercapai dan media ini adalah cara terbaik untuk dapat membantu peserta didik menuangkan ide-ide kreatif mereka ke dalam sebuah karangan.

\section{KESIMPULAN}

Berdasarkan hasil analisis data yang telah diuraikan pada bab IV, dapat disimpulkan bahwa media pembelajaran Flashcard memberikan pengaruh positif yang signifikant terhadap keterampailan menulis karangan sederhana bahasa Jerman siswa kelas XI IPA SMA Negeri 9 Makassar. Hal tersebut dibuktikan dengan hasil analisis data yang telah dilakukan dengan nilai post-test siswa setelah dilakukan uji-t pada masing-masing kelompok dengan hasil analisis data yaitu $\mathrm{t}_{\text {hitung }}=6,17>\mathrm{t}_{\text {tabel }}=1.998$ pada taraf signifikansi 0,05 yang berarti bahwa media pembelajaran Flashcard efektif dalam keterampilan menulis karangan sederhana bahasa Jerman siswa kelas XI IPA SMA Negeri 9 Makassar.

\section{DAFTAR PUSTAKA}

Arikunto, Suharsimi. 2013. Dasar-Dasar Evaluasi Pendidikan. Jakarta: Bumi Aksara.

Arsyad, Azhar. 2016. Media Pembelajaran. Jakarta: PT Raja Grafindo Jakarta Persada.

Buttner, Amy. 2013. Aktivitas Permainan Dan Strategi Penilaian Untuk Kelas Bahasa Asing. Jakarta: PT Indeks.

Dalman. 2015. Keterampilan menulis. Jakarta: PT Raja Grafindo Persada.

Indriana, Dina. 2011. Ragam Alat Bantu Media Pengajaran. Jogyakarta: Diva Press.

Mantasiah, R. 2016. Kohesi Dalam Wacana Buku Kontakte Deutsch: Suatu Kajian Analisis Wacana (Cohesion in Discourses of Kontakte Deutsch Book: a Study of Discourse Analysis). SAWERIGADING, 15(3), 336-348.

Permendiknas Nomor 22 Tahun 2006 Tentang Standar Isi.

Pemendiknas Nomor 23 Tahun 2006 Tentang Standar Kompetensi Lulusan. 
Rosidi, Imron. 2015. Menulis....Siapa Takut? (Panduan Bagi Penulis Pemula). Yogyakarta: Kanisius.

Sadiman. 2006. Media Pendidikan: Pengertian, Pengembangan, Dan Pemanfaatannya. Jakarta: PT Raja Grafindo.

Susilana, Rudi, dan Cepi Riyana.2009 Media Pembelajaran Hakikat, Pengembangan, Pemanfaatan, dan Penilaian. Bandung: CV Wacana Prima.

Wulansari, Eva. 2014. Keefektifan Penggunaan Media Flashcard Dalam Pembelajaran Keterampilan Menulis Bahasa Jerman Di Sma Negeri 1 Sedayu Bantul (diakses dari http://eprints.uny.ac.id/19117/ pada tanggal 1 Septmber2016). 